\title{
Analysing and Preventing the Problems of Liquefaction in Soils
}

\author{
Ch. Hari Naga Prasad \\ Assistant Profissor, \\ Department Of Civil Engineering. \\ KG Reddy College Of Engineering And Technology. \\ Hyderabad. Telangana.
}

\author{
M. Rathna Chary \\ Assistant Profissor, \\ Department Of Civil Engineering. \\ KG Reddy College Of EngineeringAnd Technology. \\ Hyderabad. Telangana.
}

\author{
K. Thangamani \\ Assistant Profissor, \\ Department Of Civil Engineering. \\ KG Reddy College Of Engineering And Technology. \\ Hyderabad.
}

\begin{abstract}
Aim of this project is to analyze the liquefaction susceptibility of some selected sites. The selected sites of specific data related to Standard Penetration Tests data are collected for determination of liquefaction susceptibility of these sites by using LiqIT software. From these procedures, shear stresses due to earthquake or settlements of structures are evaluated using LiqIT software for liquefaction analysis of soils. Liquefaction, which can be defined as a loss of strength and stiffness in soils, is one of the major causes of damage to buildings and infrastructure during an earthquake. To overcome a lack of comprehensive analyses of seismically induced liquefaction. The characteristics of liquefaction and its related damage to soils and foundations during earthquakes or settlements of structures. By using LiqIT software for liquefaction data analysis, test values graphs are collected for determination of liquefaction susceptibility of these sites using LiqIT soil software.

Finally we can analyse the liquefied zones or sites with the help software, for this liquefied sites prevention methods are to be given to promote anti liquefaction. Additionally, phenomena related to damage in soils and foundations induced by liquefaction are investigated and discussed.
\end{abstract}

Keywords-Liquefaction, LiqIT soil software, Factor of safety

\section{INTRODUCTION}

Liquefaction is the phenomena when there is loss of strength in saturated and cohesion less soils because of increased pore water pressures and hence reduced effective stresses due to dynamic loading. It is a phenomenon in which the strength and stiffness of a soil is reduced by earthquake shaking or other rapid loading. Although earthquakes often triggers this increase in pore water pressure, but activities such as blasting can also cause an increase in pore water pressure. When liquefaction occurs, the strength of the soil decreases and the ability of a soil deposit to support the construction above it. Soil liquefaction can also exert higher pressure on retaining walls, which can cause them to slide or tilt. This movement can cause destruction of structures on the ground surface and settlement of the retained soil. As India experiencing lots of seismic threats, liquefaction is one of the major types of ground failure. 1934 BiharNepal earthquake was one of the worst earthquakes in the history of Nepal and Bihar, India. A magnitude of 8.0 occurred on 15 January and caused widespread damage in northern Bihar and in Nepal. A large number of sand fountains were noticed during the Bihar earthquake (Housner, 1958, Dunnet al 1939). On August 6, 1988; several parts of the north-eastern India were rocked by an earthquake. The tremors were also felt in Nepal, Bangladesh, Burma and Soviet Union. On August 21, 1988 another earthquake occurred in the Bihar Nepal Border region.

A Large scale of liquefaction has been reported during these two earthquakes. After the 2001 Bhuj earthquake and recently 2015 Nepal earthquake attracted the greater attention to liquefaction studies. Present study liquefaction analysis carried out in Places along river Godavari is erosion, fault controlled and hence vulnerable to the seismicity of low to moderate intensity. Therefore, it is essential to take up seismic hazard studies at the micro level to improve safety norms for the port structure, industrial structures and underground pipelines

\section{OBJECTIVES OF PRESENT STUDY}

The present study, soil liquefaction analysis is carried out in Places along river Godavari using 20 Standard penetration test borehole data collected from various sites. Using semi empirical equations developed by Idriss finding factor of safety. Factor of safety can be determined from the cyclic stress ratio and cyclic resistance ratio.

1. Peak Ground Acceleration (PGA) is an important parameter, occurred during an earthquake shaking at a location. In the present study PGA values are evaluated using a computer program LiqIT

2. Analysing the liquefied zones of particular locations through the LiqIT software.

3. We will get the detailed information regarding liquefied zones in the form of :

I. Graphs.

II. Tabular values.

III. Identification icons.

IV. Factor of safety. 
V. FS greater than 1 (no liquefaction)

VI. FS less than 1 (Liquefaction effected).

\section{EVALUATION OF LIQUEFACTION SUSCEPTIBILITY}

During cyclic undrained loading, like those imposed by earthquake shaking, almost all saturated cohesionless soils are subjected to significant pore pressure build-up. If there is shear stress reversal, the effective stress state can drop rapidly to zero. When a soil

element reaches the condition of essentially zero effective stress, the soil has very little stiffness and large deformations. This phenomenon is generally referred to as liquefaction Semi-empirical procedures for evaluating liquefaction potential of cohesionless soils during earthquakes basically consist of analytical approaches to explain experimental findings of past case histories, and the development of a suitable in-situ index to represent soil liquefaction characteristics.

\section{METHODS OF REDUCING LIQUEFACTION HAZARDS}

By Avoiding Liquefaction Susceptible Soils.

_ Build Liquefaction Resistant Structures.

- Improve the Soil

- Construction on liquefaction susceptible soils is to be avoided.

- The soil at a particular building site according to the various criterias available to determine the liquefaction potential of the soil in a site

- The structure constructed should be liquefaction resistant

_ The mitigation of the liquefaction hazards by improving the strength, density and drainage characteristics of the soil.

\section{SUSCEPTIBILITY OF SOILS TO LIQUEFACTION IN EARTHQUAKES}

Liquefaction is most commonly observed in shallow, loose, saturated cohesion less soils subjected to strong ground motions in earthquakes. Unsaturated soils are not subject to liquefaction because volume compression does not generate excess pore water pressure. Liquefaction and large deformations are more associated with contractive soils while cyclic softening and limited deformations are more likely with expansive soils. In practice, he liquefaction potential in a given soil deposit during an earthquake is often evaluated using in-situ penetration tests and empirical procedures.

Since liquefaction phenomena arise because of the tendency of soil grains to rearrange when sheared, any factor that prevents the movement of soil grains will increase the liquefaction resistance of a soil deposit. Particle cementation, soil fabric, and again are some of the important factors that can hinder soil particle movement. Stress history is also crucial in determining the liquefaction resistance of a soil.

\section{GROUND FAILURE RESUILTING FROM SOIL LIQUEFACTION}

National Research Council (The Liquefaction..1985) lists eight types of ground failurecommonly associated with the soil liquefaction in earthquakes:

Sand boils resulting in land subsidence accompanied by a relatively minor change.
Failure of retaining walls due to increased lateral loads from liquefied backfill orloss of support from the liquefied foundation soils.

Ground settlement, generally linked with some other failure mechanism.

Flow failures of slopes resulting in large down slope movements of a soil mass.

Buoyant rise of buried structures such as tanks.

Lateral spreads resulting from the lateral movements of gently sloping ground.

Loss of bearing capacity resulting in foundation failures.

Ground oscillation involving back and forth displacements of intact blocks of surface soil.

\section{LITERATURE REVIEW}

When dense sands are sheared monotonically, the soil gets compressed first and then it gets dilated as sand particles move up and over one another. When dense saturated sands are sheared impeding the pore water drainage, their tendency of volume increase results in a decrease in pore water pressure and an increase in the effective stress and shear strength. When dense sand is subjected to cyclic small shear strains

under undrained pore water conditions excess pore water pressure may be generated in each load cycle leading to softening and the accumulation of deformations. However, at lager shear strains, increase in volume relieves the excess pore water pressure resulting in an increased shear resistance of the soil.After initial liquefaction if large deformations are prevented because of increased undrained shear strength then it is termed, limited liquefaction (Finn 1990). When dense saturated sands are subjected to static loading they have the tendency to progressively soften in undrained cyclic shear achieving limiting strains which is known as cyclic mobility.(Castro 1975; Castro and Poulos 1979). Cyclic mobility should not be confused with liquefaction. Both can be distinguished from the very fact that a liquefied soil displays no appreciable increase in shear resistance regardless of the magnitude of deformation (Seed 1979) Soils undergoing cyclic mobility first soften subjected to cyclic loading, but later when monotonically loaded without drainage stiffen because tendency to increase in volume reduce the pore pressures. During cyclic mobility, the driving static shear stress is less than the residual shear resistance and deformations get accumulated only during cyclic loading. However, in laymans language, a soil failure resulting from cyclic mobility is referred to as liquefaction. Robertson (1994) termed this, cyclic liquefaction. It involves some deformation occurring while static shear stresses exceed the shear resistance of the soil (when the state of zero effective stress is approached). However the deformations stop after cyclic loading ends as the tendency to expand quickly results in strain hardening. This type of failure in saturated, dense cohesion less soils is also referred to as liquefaction but with limited deformations. According to Selig and Chang (1981) and Robertson (1994), a dilative soil can attain a state of zero effective stress and shear resistance.Cyclic loads may produce a reversal in the shear stress direction when the initial static shear stress is low i.e. the stress path passes 
through a condition which is known as state of zero shear stress.

\section{METHODOLOGY}

The stress-based approach for evaluating the potential for liquefaction triggering, by Idriss and Boulanger (2004). The basic framework, as adopted compares the earthquake induced cyclic stress ratios (CSR) with the cyclic resistance ratios (CRR) of the soil. The components of this Methodology, as briefly summarized below, were developed to provide a rational treatment of the various factors that affect penetration resistance and cyclic resistance.

\section{Evaluation of Cyclic Stress Ratio (CSR)}

The earthquake-induced CSR, at a given depth, $\mathrm{z}$, within the soil profile, is usually expressed as a representative value (or equivalent uniform value) equal to $65 \%$ of the maximum cyclic shear stress ratio.

\section{Evaluation of Cyclic Resistance Ratio}

The cyclic resistance ratio represents the liquefaction resistance of the soil, expressed as CRR. That means cyclic stress required to induce liquefaction for a soil stratum.

\section{Magnitude Scaling Factor}

The magnitude scaling factor (MSF) is used to account for duration effects (i.e., number of loading Cycles) on the triggering of liquefaction. The MSF relationship was derived by combing.

\section{Factor of Safety}

Factor of safety is defined as the ratio of cyclic resistance ratio (CRR) to cyclic stress ratio (CSR).

Factor of Safety $=$ Cyclic Resistance Ratio $/$ Cyclic Stress Ratio

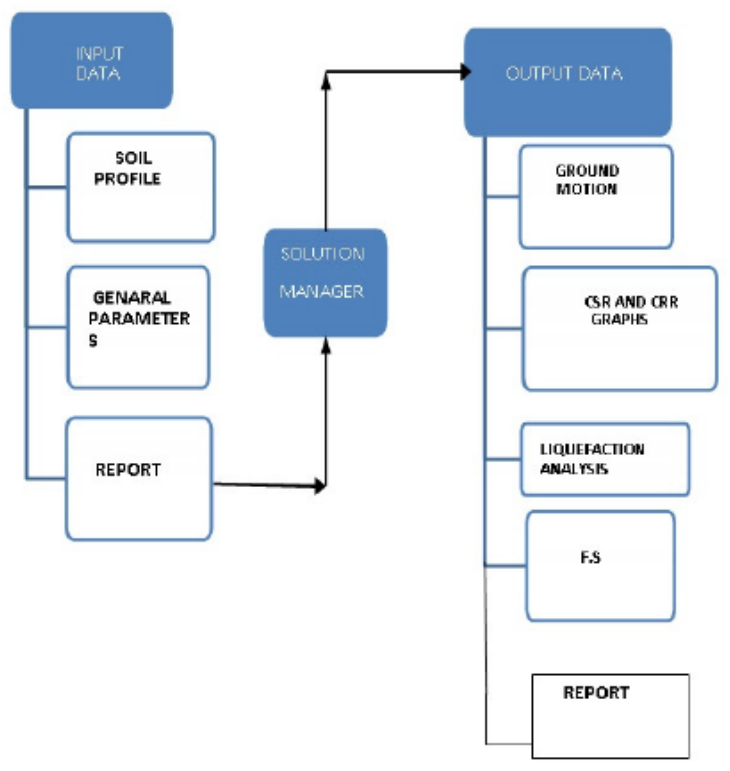

Fig. 3.1 Flow Chart

Flow Chart

\begin{tabular}{|l|l|l|}
\hline \multicolumn{3}{|c}{ SPT Corrections Listed by Robertson } \\
\hline Factor & \multicolumn{1}{|c|}{$\begin{array}{r}\text { Equipment } \\
\text { Variable }\end{array}$} & $\begin{array}{l}\text { Correction } \\
\text { for SPT zones }\end{array}$ \\
\hline Overburden pressure & 0.5 \\
\hline Energy ratio & Donut hammer & $0.5-1$ \\
\hline Energy ratio & $\begin{array}{l}\text { Automatic trip } \\
\text { donut }\end{array}$ & $0.8-1.3$ \\
\hline Energy ratio & Hammer & 0.6 \\
\hline Borehole diameter & $65-115 \mathrm{~mm}$ & 1 \\
\hline Borehole diameter & $150 \mathrm{~mm}$ & 1.05 \\
\hline Borehole diameter & $200 \mathrm{~mm}$ & 1.15 \\
\hline Rod length & i $\mathrm{m}$ & 0.75 \\
\hline Rod length & $3-4 \mathrm{~m}$ & 0.8 \\
\hline Rod length & $4-6 \mathrm{~m}$ & 0.85 \\
\hline Rod length & $6-10 \mathrm{~m}$ & 0.95 \\
\hline Rod length & $10-30 \mathrm{~m}$ & 1 \\
\hline Sampling method & $\begin{array}{l}\text { Standard } \\
\text { sampler }\end{array}$ & $\begin{array}{l}1 \\
\text { without liner }\end{array}$ \\
\hline Sampling method & Sampler \\
\hline
\end{tabular}

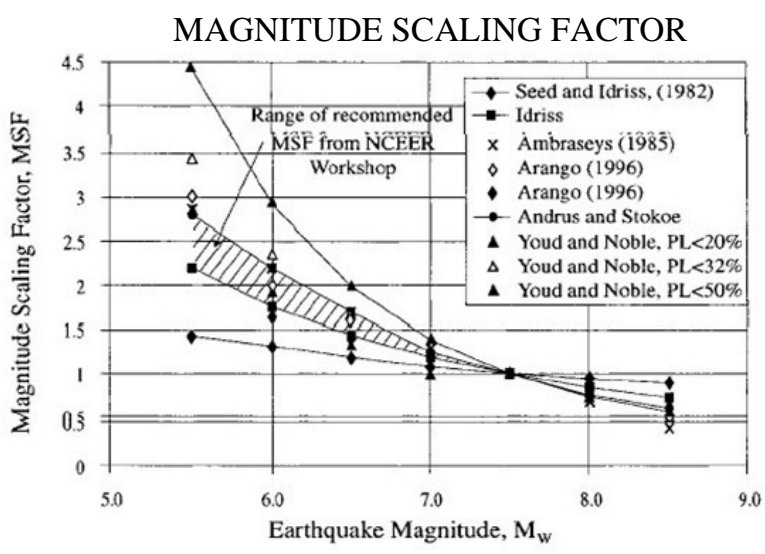

INTRODUCTION TO LIQIT SOFTWARE

Seismic ground acceleration plays an important role in assessing effects of earthquakes on the built environment, persons, and the natural environment. Earthquake shaking generally occurs in all three directions. Therefore, PGA is often split into the horizontal and vertical components. In present study peak ground acceleration is calculated using a computer based program, LiqIT.

\section{LIQIT PROGRAME STRUCTURE}

LiqIT is designed to provide an intuitive interface that simplifies and speeds the process of performing and interpreting the results of ground response analyses. The program is organized into three managers - an Input data Mnager, a Solution, and an Output data Manager - and a Report. In the normal sequence of operations, the user will move from the Input data to the Solution Manager and then on to the Output data, as indicated graphically below.

\section{INPUT DATA MANAGER}

The Input Data Manager allows all input data to be entered, checked, and saved prior to program execution. The Input data 
Manager provides a series of forms on which the required data can be entered, and on which the desired output can be specified. Input data manager consists of soil profile, input motions and report. LiqIT allows you to view a variety of potential input motions and select the ones that are most appropriate for the analysis.

\section{SOLUTION MANAGER}

The Solution Manager performs the actual ground response analysis. It requires that the user specify a valid input data file (with the data extension) and then performs the required that allows the user to track the progress of the analysis. Upon completion of the analysis, the Solution Manager saves he results in a file.

\section{OUTPUT DATA MANAGER}

The Output data Manager allows the user to generate a wide range of plots of the results of the analysis. It requires that the user specify a valid output data file, and then provides a number of forms for plotting time histories, spectra, variations of parameters with depth, and for computation of scalar parameters. The Output data Manager also allows the user to view an animation of the horizontal displacements throughout the soil profile- many users find this feature very helpful for developing an intuitive understanding of the response of the soil profile.

\section{REPORT}

The Report produced by a word processor that is built into LiqIT. The Report allows the user to keep a record of each analysis. All input data is automatically written to the Report and updated when the Report is accessed. Many users find the Report useful for internal documentation of their analyses and for preparation of project reports for their clients. The below mentioned required data values are got through consultancy companies. LiqIT Software consists of:
1. Depth
2. Nspt
3. Fine content
4. Gamma

Input Parameters

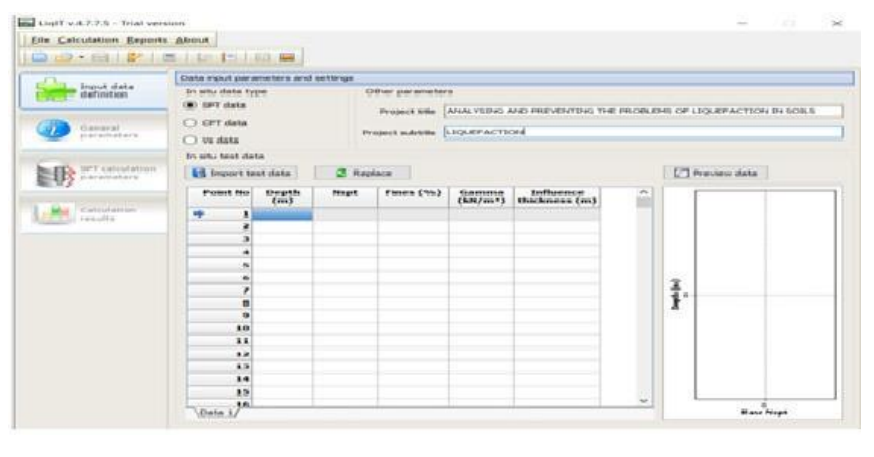

General Parameters

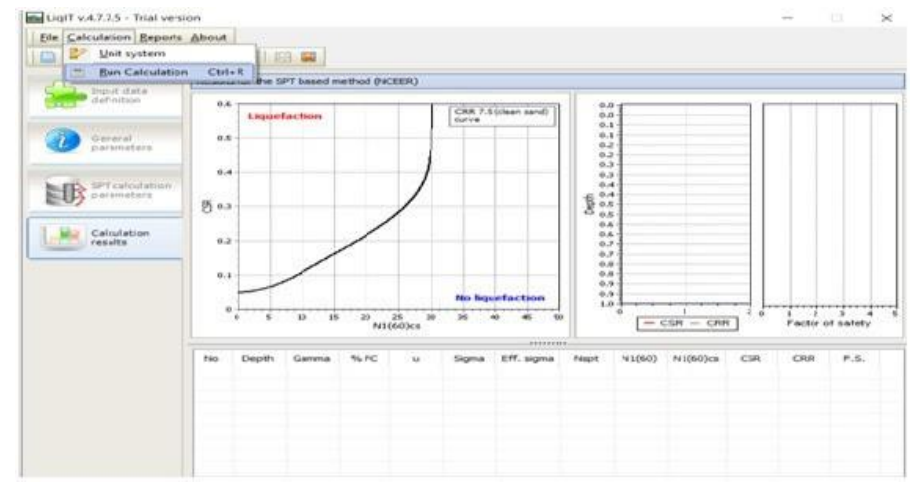

Calculation Details

Procedure Involved in LiqIT Software
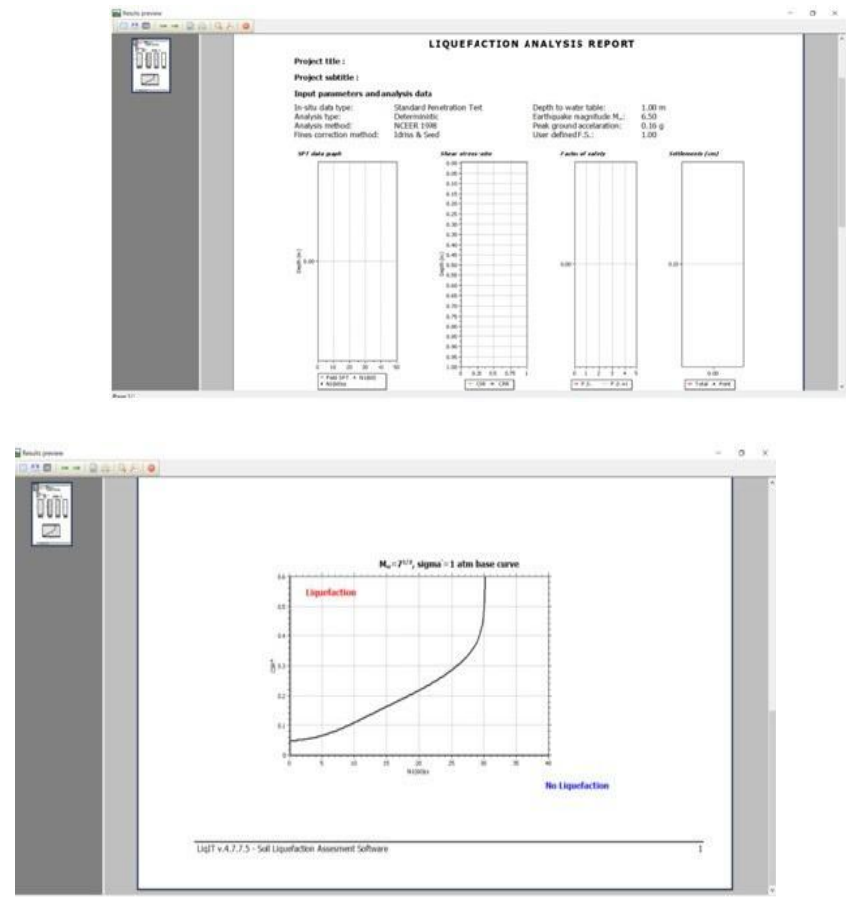

Analyzing of Liquefaction

Design of Factor of Safety

\section{CALCULATIONS AND DISCUSSIONS}

In present study $\mathrm{N}$-values obtained from 20 locations at different depths are considered for assessment of liquefaction potential of soil. The Soil has been analyzed for peak ground acceleration levels obtained from LiqIT and Factor of safety is calculated by using Idriss method.

\section{Liquefaction susceptibility through LiqIT software}

By calculating the factor of safety using the Idriss method, using the parameters, peak ground acceleration and SPT $N$ values the susceptibility of liquefaction is measured along the borehole depth. 
Susceptibility of liquefaction is measured along the depths of $2,6,10$, up to $20 \mathrm{~m}$ for 20 locations. The liquefaction susceptibility of various locations at 2,6 , $10 \mathrm{~m}$ depth are presented in tables and graphs with the help of LiqIT soil software.

\section{Bore Hole Locations}

The Present Study Liquefaction Analysis is carried at the following places:
1. Yanam
2. Rajahmundry
3. Polavaram
4. Tallarevu
5. Katrenikona

The present study is carried out along 20 various sites as stated above, We have collected the SPT borehole data from JNTU Kakinada, geotechnical laboratory report section. We have also prepared a borehole location analysis of various sites using LiqIT software.

\section{List of 20 Sites SPT Zones:}

Details of locations Regarding liquefaction for SPT sites or zones:

YANAM: 7 Bore holes (SPT data)

RAJAHMUNDRY : 5 Bore holes (SPT data)

POLAVARAM: 3 Bore holes (SPT data)

TALLAREVU: 3 Bore holes (SPT data)

KATRENIKONA: 2 Bore holes (SPT data)

\section{RESULTS}

Susceptibility of Liquefaction at a Depth of $2 \mathrm{~m}$ by Idris and Boulanger Method Susceptibility of Liquefaction at a Depth of $6 \mathrm{~m}$ by Idris and Boulanger Method Susceptibility of Liquefaction at a Depth of $10 \mathrm{~m}$ by Idris and Boulanger Method

Liquefaction Analysis: 1

\begin{tabular}{|c|l|c|}
\hline S.No & Location & $\begin{array}{c}\text { Liquefaction at a } \\
\text { depth of } \mathbf{~ m}\end{array}$ \\
\hline 1 & $\begin{array}{l}\text { BH-2 SAVITRI } \\
\text { NAGAR,YANAM }\end{array}$ & NO \\
\hline 2 & $\begin{array}{l}\text { BH-3 SAVITRI } \\
\text { NAGAR,YANAM }\end{array}$ & YES \\
\hline 3 & BH-1 ISLAND 5,YANAM & YES \\
\hline 4 & BH-2 ISLAND 5,YANAM & NO \\
\hline 5 & BH-3 ISLAND 5,YANAM & YES \\
\hline 6 & $\begin{array}{l}\text { BH-2 } \\
\text { DARIYALATHIPPA,YANAM }\end{array}$ & YES \\
\hline 7 & $\begin{array}{l}\text { BH-3 } \\
\text { DARIYALATHIPPA,YANAM }\end{array}$ & NO \\
\hline 8 & $\begin{array}{l}\text { HUKUMPETA,RAJAHMUND } \\
\text { RY }\end{array}$ & YES \\
\hline 9 & $\begin{array}{l}\text { PIDINGOYYI,RAJAHMUND } \\
\text { RY }\end{array}$ & YES \\
\hline 10 & $\begin{array}{l}\text { QUARYROAD,RAJAHMUND } \\
\text { RY }\end{array}$ & YES \\
\hline
\end{tabular}

Liquefaction table 2:

\begin{tabular}{|c|l|c|}
\hline S.No & Location & $\begin{array}{c}\text { Liquefaction at } \\
\text { a depth of 2m }\end{array}$ \\
\hline 11 & ACYCOLONY RAJAHMUNDRY & NO \\
\hline 12 & $\begin{array}{l}\text { ACY COLONY } \\
\text { RAJAHMUNDRY }\end{array}$ & NO \\
\hline 13 & $\begin{array}{l}\text { BNRGSKBUIDINGS } \\
\text { POLAVARAM }\end{array}$ & YES \\
\hline 14 & $\begin{array}{l}\text { BNRGSK BUIDINGS } \\
\text { POLAVARAM }\end{array}$ & YES \\
\hline 15 & $\begin{array}{l}\text { BHYRAVAPALEM } \\
\text { POLAVARAM }\end{array}$ & NO \\
\hline 16 & $\begin{array}{l}\text { BNRGSK BUIDINGS } \\
\text { TALLAREVU }\end{array}$ & NO \\
\hline 17 & $\begin{array}{l}\text { BNRGSK BUIDINGS } \\
\text { TALLAREVU }\end{array}$ & $\begin{array}{l}\text { YES } \\
\text { TALLAREVU }\end{array}$ \\
\hline 19 & $\begin{array}{l}\text { BNRGSK BUIDINGS } \\
\text { KATRENIKONA }\end{array}$ & YES \\
\hline 20 & $\begin{array}{l}\text { GOLLAGARVU } \\
\text { KATRENIKONA }\end{array}$ \\
\hline
\end{tabular}

Liquefaction Analysis: 3

\begin{tabular}{|c|l|c|}
\hline S.No & Location & $\begin{array}{c}\text { Liquefaction at a } \\
\text { depth of } \mathbf{6 m}\end{array}$ \\
\hline 1 & $\begin{array}{l}\text { BH-2 SAVITRI NAGAR, } \\
\text { YANAM }\end{array}$ & YES \\
\hline 2 & $\begin{array}{l}\text { BH-3 SAVITRI NAGAR, } \\
\text { YANAM }\end{array}$ & YES \\
\hline 3 & BH-1 ISLAND, YANAM & NO \\
\hline 4 & BH-2 ISLAND, YANAM & YES \\
\hline 5 & BH-3 ISLAND, YANAM & YES \\
\hline 6 & $\begin{array}{l}\text { BH-2 DARIYALATHIPPA, } \\
\text { YANAM }\end{array}$ & NO \\
\hline 7 & $\begin{array}{l}\text { BH-3 DARIYALATHIPPA, } \\
\text { YANAM }\end{array}$ & NO \\
\hline 8 & $\begin{array}{l}\text { HUKUMPETA, } \\
\text { RAJAHMUNDRY }\end{array}$ & YES \\
\hline 9 & $\begin{array}{l}\text { PIDINGOYYI, } \\
\text { RAJAHMUNDRY }\end{array}$ & YES \\
\hline 10 & $\begin{array}{l}\text { QUARYROAD, } \\
\text { RAJAHMUNDRY }\end{array}$ \\
\hline
\end{tabular}

Liquefaction Analysis: 4

\begin{tabular}{|c|l|c|}
\hline S.No & Location & $\begin{array}{c}\text { Liquefaction } \\
\text { at a depth of } \\
\mathbf{6 m}\end{array}$ \\
\hline 11 & $\begin{array}{l}\text { BH-1 ACY COLONY, } \\
\text { RAJAHMUNDRY }\end{array}$ & NO \\
\hline 12 & $\begin{array}{l}\text { BH-2 ACY COLONY, } \\
\text { RAJAHMUNDRY }\end{array}$ & NO \\
\hline 13 & $\begin{array}{l}\text { BH-1 BNRGSK, } \\
\text { I.POLAVARAM }\end{array}$ & YES \\
\hline 14 & $\begin{array}{l}\text { BH-2 BNRGSK, } \\
\text { I.POLAVARAM }\end{array}$ & NO \\
\hline 15 & $\begin{array}{l}\text { BHYRAVAPALAM, } \\
\text { I.POLAVARAM }\end{array}$ & NO \\
\hline 16 & BH-1 BNRGSK, TALLAREVU & YES \\
\hline 17 & BH-2 BNRGSK, TALLAREVU \\
\hline 18 & TALLAREVU & YES \\
\hline 19 & BNRGSK, KATRENIKONA & YES \\
\hline 20 & $\begin{array}{l}\text { GOLLAGARVU, } \\
\text { KATRENIKONA }\end{array}$ & \\
\hline
\end{tabular}


Liquefaction Analysis: 5

\begin{tabular}{|c|l|c|}
\hline $\begin{array}{c}\text { S.N } \\
\mathbf{o}\end{array}$ & $\begin{array}{l}\text { Locatio } \\
\text { n }\end{array}$ & $\begin{array}{c}\text { Liquefaction } \\
\text { at a depth of } \\
\mathbf{1 0 m}\end{array}$ \\
\hline 1 & $\begin{array}{l}\text { BH-2 SAVITRI } \\
\text { NAGAR YANAM }\end{array}$ & YES \\
\hline 2 & $\begin{array}{l}\text { BH-3 SAVITRI } \\
\text { NAGAR YANAM }\end{array}$ & NO \\
\hline 3 & ISLAND YANAM & NO \\
\hline 4 & ISLAND YANAM & NO \\
\hline 5 & ISLAND YANAM & YES \\
\hline 6 & $\begin{array}{l}\text { DARIYALATHIPPA } \\
\text { YANAM }\end{array}$ & YES \\
\hline 7 & $\begin{array}{l}\text { DARIYALATHIPPA } \\
\text { YANAM }\end{array}$ & NO \\
\hline 8 & $\begin{array}{l}\text { HUKUMPETA } \\
\text { RAJAHMUNDRY }\end{array}$ & NO \\
\hline 9 & $\begin{array}{l}\text { PIDINGOYYI } \\
\text { RAJAHMUNDRY }\end{array}$ & YES \\
\hline 10 & $\begin{array}{l}\text { QUARYROAD } \\
\text { RAJAHMUNDRY }\end{array}$ & NO \\
\hline
\end{tabular}

Liquefaction Analysis: 6

\begin{tabular}{|c|l|c|}
\hline S.No & Location & $\begin{array}{c}\text { Liquefaction } \\
\text { at a depth of } \\
\mathbf{1 0 m}\end{array}$ \\
\hline 11 & $\begin{array}{l}\text { BH-1 ACY } \\
\text { COLONY,RAJAHMUNDRY }\end{array}$ & NO \\
\hline 12 & $\begin{array}{l}\text { BH-2 ACY } \\
\text { COLONY,RAJAHMUNDRY }\end{array}$ & NO \\
\hline 13 & $\begin{array}{l}\text { BH-1 } \\
\text { BNRGSK,I.POLAVARAM }\end{array}$ & NO \\
\hline 14 & $\begin{array}{l}\text { BH-2 } \\
\text { BNRGSK,I.POLAVARAM }\end{array}$ & YES \\
\hline 15 & $\begin{array}{l}\text { BHYRAVAPALEM,I.POLAVA } \\
\text { RAM }\end{array}$ & YES \\
\hline 16 & BH-1 BNRGSK,TALLAREVU & YES \\
\hline 17 & BH-2 BNRGSK,TALLAREVU & YES \\
\hline 18 & TALLAREVU & YES \\
\hline 19 & BNRGSK,KATRENIKONA & NO \\
\hline 20 & $\begin{array}{l}\text { GOLLAGARVU, } \\
\text { KATRENIKONA }\end{array}$ & \\
\hline
\end{tabular}

\section{CONCLUSION}

The present work is carried out to analyse the liquefaction potential and liquefied sus- ceptibility in some places along River Godavari. The 20 bore hole data is collected from the places of Yanam, Rajahmundry, I.Polavaram, Tallarevu Katrenikona. A Semi Empirical Method, Idriss and Boulanger is used to determine, the liquefaction potential.

\section{CONCLUSIONS DRAWN FROM THE STUDY ABOUT LIQUEFACTION ANALYSIS :}

Soil layers with corrected SPT blow count () less than 14 have been known to be liquefy in most of the cases.
Soil layers with corrected SPT blow count () greater than 20 have been known to be safe against liquefaction in most of the cases.

The liquefaction potentiality which depends on vertical effective stress, from this analysis in all cases vertical effective stress greater than $95 \mathrm{KN} / \mathrm{m} 2^{\wedge}$ is safe against liquefaction.

In Yanam region 7 Bore Hole Log Data are analyzed in which most cases re- vealed that Soil undergoes Liquefaction at Depths Ranging 3m-5m.

In Rajahmundry region 5 Bore Hole Log Data are analyzed in which Soil un- dergone Liquefaction in 2 cases while in remaining 3 cases soil is safe against liquefaction.

In I.Polavaram region 3 Bore Hole Log Data are analyzed in which all cases revealed that Soil undergoes Liquefaction at Depths Ranging 2.5m-6m.

In Tallarevu region 3 Bore Hole Log Data are analyzed in which most cases revealed that Soil is safe against Liquefaction.

In Katrenikona region 2 Bore Hole Log Data are analyzed in which Soil under- goes Liquefaction in both the cases.

\section{REFERANCE}

[1] M. Idriss and R. W. Boulanger, (2004) Semi-empirical Procedures for Evaluat- ing Liquefaction Potential During Earthquakes, Proceedings of the 11th ICSDEE 3rd ICEGE, pp 32 56, January 7

[2] Sladen, J. A., DHollander, R. D., and Krahn, J.(1985) The liquefaction of sands, a collapse surface approach. Can. Geotech. J., 22, 564578.

[3] Finn, W.L., Ledbetter, R. H., and Wu, G. (1994): Liquefaction in silty soils: design and analysis, Ground failures under seismic conditions, Geotechnical Special Publication No 44, ASCE, Reston, 5179.

[4] Castro, G., (1975) Liquefaction and cyclic mobility of saturated sands. Journal of the Geotechnical Engineering Division, ASCE, 101 (GT6), 551-569.

[5] Seed, H. B. (1979) Soil Liquefaction and Cyclic Mobility Evaluation for Level Ground During Earthquake, Journal of Geotechnical Engineering Division, ASCE, Vol 105, No. GT2, pp 201-225.

[6] Selig, E.T., and Chang C.S.(1981) soil failure modes in undrained cyclic loading J. Geotech. Engg. Div., ASCE, Vol.107, No.GT5, May, pp 539-551.

[7] Robertson, P.K. (1994) suggested terminology for liquefaction: An Internal CANLEX Report.

[8] Robertson, P.K. and Fear, C.E. (1996), Soil liquefaction and its evaluation based on SPT and CPT, Liquefaction Workshop, January 1996.

[9] National Research Councils Committee on Earthquake Engineering (1985).

[10] Krinitzky et al.1993 fundamentals of earthquake resistant construction. 